\title{
Job-hopping amongst African Black senior management in South Africa
}

\author{
Authors: \\ Khanyile C.C. Nzukuma ${ }^{1}$ \\ Mark Bussin ${ }^{1}$ \\ Affiliations: \\ ${ }^{1}$ Department of Industrial \\ Psychology and People \\ Management, University of \\ Johannesburg, South Africa \\ Correspondence to: \\ Mark Bussin \\ Email: \\ drbussin@mweb.co.za \\ Postal address: \\ PO Box 973, Saxonwold 2132, \\ South Africa \\ Dates: \\ Received: 08 Feb. 2011 \\ Accepted: 24 Aug. 2011 \\ Published: 09 Nov. 2011 \\ How to cite this article: \\ Nzukuma, K.C.C., \& Bussin, \\ M. (2011). Job-hopping \\ amongst African Black \\ senior management in \\ South Africa. SA Journal \\ of Human Resource \\ Management/SA Tydskrif vir \\ Menslikehulpbronbestuur, \\ 9(1), Art. \#360, 12 pages. \\ http://dx.doi.org/10.4102/ \\ sajhrm.v9i1.360
}

Orientation: The study focuses on understanding labour turnover trends amongst African Black senior managers in South Africa. There is a perception that turnover amongst African Black senior managers is higher than average. There is also a perception that African Black senior managers are only motivated by financial rewards when considering job change.

Research purpose: The study focused on understanding why African Black senior managers have a propensity to change jobs and how organisations can resolve the trend.

Motivation for the study: To develop a better understanding of the push and pull factors for African Black senior managers in organisations.

Research design, approach and method: The research was conducted in two phases, namely as part of a qualitative study and a quantitative study: Creswell (2003) refers to this approach as triangulation. The target population was African Black senior managers on the database of a large Human Resources Consultancy, The South African Rewards Association and the Association of Black Actuaries and Investment Professionals (ABSIP) $(n=2600)$. A total of 208 usable responses were received.

Main findings: The main findings and contribution to the field of study was that African Black senior managers do not trust organisations with their career development. They would rather take control of their own career development by moving from organisation to organisation to build their repertoire of skills and competence. They want to be in charge of their careers. This finding has profound implications for organisations employing African Black managers in the senior cadre.

Practical/managerial implications: Managers of African Black senior managers need to create attractive employee value propositions that address the main findings.

Contribution/value-add: The research shows that African Black senior managers generally seek corporate environments that encourage a sense of belonging and with a clear career growth plan.

\section{Introduction}

\section{Key focus of the study}

The Broad Based Black Economic Empowerment (BBBEE) Act of 2003 and the Employment Equity Act of 1998 have disrupted the labour market in South Africa by accelerating the legislative need to appoint African Black senior managers in organisations. There is at the same time an undersupply of candidates meeting the requirements because of the education system and job reservation policies under the apartheid government. One of the outcomes of the operating environment is a perception that there is an abnormally high job mobility rate amongst African Black senior managers. The South African Employment Equity Act of 1998 defines Black people as people of Coloured, Indian and African descent. African Black senior managers are the unit of study because of the unique position they occupy, as part of the small group of skilled Black management talent in a country where the population consists of $79 \%$ Black people.

\section{Background to the study}

The injustice suffered by victims of racial discrimination and related intolerance are well documented, namely limited employment opportunities, segregation and endemic poverty (Hay, 2001). The development of a Black middle market has led to a high demand for African Black senior management, with their intrinsic understanding of and established relationships within the Black middle market. The limited number of qualified and experienced Black professionals
C 2011. The Authors. Licensee: AOSIS OpenJournals. This work is licensed under the Creative Commons Attribution License. 
has created a number of perceptions around the mobility of top Black talent. Fourteen years into the new democratic dispensation, many companies are positioning themselves as being the employer of choice, and there is a distinct shift towards workplace equality, both gender-wise and in line with affirmative action (Czakan, 2006).

\section{Research objectives}

The main research aim is to understand why African Black senior managers have a propensity to leave organisations. The main objective of this research is to understand factors that will push and pull them to explore opportunities outside their organisations. The first secondary objective is to evaluate statistics on demographic composition of senior management and top management. The secondary objective is to evaluate international literature to identify similarities in transformation challenges and solutions applied in international case studies. The secondary objectives were selected to reflect on demographic representation of African Black senior managers in South Africa to determine the extent of African Black senior management skill. Another reason for selecting the secondary objectives is to evaluate how this challenge has been addressed in societies with similar challenges in the world.

\section{Trends from the research literature}

International literature from the United States of America (USA) and India indicates that after 40 years America has not achieved demographic transformation as was planned. Affirmative action programmes in the United States have been effective in reducing, but not eliminating, discriminating practices (Alleyne, 2005); for example, in 1963 a Black male worker earned $50 \%$ of the equivalent of a White male worker and by 1993 this was raised to $75 \%$ (Berger \& Berger, 2004). Despite the limited success of affirmative action programmes in the USA, discrimination remains in existence, with education and work experience differences accounting for $50 \%$ of the wage gap between Black and White male workers. Whilst some may claim that affirmative action has meant reverse discrimination in terms of White people, White privilege remains intact (Berger \& Berger, 2004). South African literature is minimal on African Black senior managers but extensive on knowledge worker literature. Sutherland (2003) maintains that knowledge workers market their skills and evaluate the value of return. The literature evaluates push factors such as discrimination, lack of development and lack of mentorship. Pull factors such as entrepreneurship and remuneration are also evaluated. The role of line management in being an enabler for an attractive employment environment is emphasised.

\section{The potential value-add of the study}

Demographic transformation of the South African economy as the next phase after the political transformation into the new democratic political order in 1994 is of major significance. From a business operation view, a demographic representative organisation will satisfy the diverse needs of their targeted customer base more effectively. A demographic representative labour force will ensure they bring culturally relevant products to the market (Ngambi, 2002). Labour turnover has been a challenge in the South African economy and more critical in the African Black senior management labour segment, because of a small talent pool. The study will contribute in constructing tools which will enable line management to establish an environment that creates a sense of belonging. This research will add value to the current debate about causes of labour turnover within the African Black senior management labour segment.

The next sections cover a synthesis and critical evaluation of the literature, research design, findings and a discussion outlining recommendations and implications of the study.

\section{Synthesis and critical evaluation of the literature}

\section{Conceptual definitions of key concepts}

For the purposes of this research, definitions will be linked to the two main subjects for discussion, namely African Black senior managers and labour turnover. In 1998, the South African Government passed the Employment Equity Act No 55 of 1998. The purpose of this legislative Act was to ensure that designated population groups in South Africa are fully represented at all levels of the South African private and public sector. Designated groups are Black people (i.e. African, Asian and Coloured people), all women and people with disabilities. These groups are the population groups that have been deprived of opportunities in the era of the National Party rule in South Africa (1948-1994). Labour turnover is referred to as an individual's estimated probability that they will stay in an employing organisation. Meanwhile, Hamori (2010) defined labour turnover intentions as conscious wilfulness to seek for opportunities in other organisations.

\section{Literature review}

The main objective of the study and the literature review was to develop a deep understanding of reasons why African Black senior managers leave organisations. The literature review, divided into three parts, was based on main and secondary research objectives. An international literature review on countries that have had similar transformation challenges as South Africa was conducted, and secondly an analysis of the demographic landscape of senior management in South African corporate was conducted. Lastly, a review of push and pull factors, that cause African Black senior managers to leave their organisations, was established.

\section{Transformation in the United States of America and India}

Affirmative action in the USA is about 40 years old, however, it is not constitutionally guaranteed and there are no formal quotas required as in the South African affirmative action policy (Johnson, 2000). More than 30 years of social and political pressure to diversify corporate personnel and management teams have resulted in more African-American managers but a negligible gain for African-American men in powerful decision-making jobs in corporate America (Allen 
\& Griffith, 1999). Despite gains in entry, African-American managers stumble on their way up the corporate ladder in corporate America thereby failing to make key inroads in decision-making positions and in the racial distribution of power.

Neoclassical economic theories and social structural explanations of race-based inequality in labour markets often are argued as oppositional insights. Human capital theory in economic literature and status attainment theory in sociology presume that economic achievement amongst Black people is a colour blind function of supply side characteristics, such as education, ability and individual preferences, and not race-conscious social policies and preferences (Johnson, 2000). Lamb (2007) disagreed with this view and stated that lack of marketable skills, a dependent mentality, inferior education, and even relatively lower intelligence quotients (IQs), are reasons for Black people to struggle to gain parity with White people. Allen and Griffith (1999) countered that people's economic attainments are determined by structural elements of the labour market. Opportunity structure and human capital are linked. Differences in education and work experience account for $50 \%$ of Black and White men. The United States image of a meritocracy has contributed to a slow pace of transformation. Believing in merit in terms of who gets a job and the use of psychometric tests is seen as standard criteria, whilst the fallacy with these instruments is that they have emerged out of the experiences, cultures and viewpoints of the dominant group which is White.

The important deviation from South Africa's application of affirmative action is that in the USA, affirmative action programmes must be limited in time and periodically reviewed to assess if they remain necessary. Affirmative action programmes in the USA have been effective in reducing, but not eliminating, discriminating practices (Alleyne, 2005). Whilst some may claim that affirmative action has meant reverse discrimination on White people, White privilege remains intact (Berger \& Berger, 2004). The trend of continued enhancement of White privilege is also evident in South Africa, as illustrated in the Commission of Employment Equity reports (2000-2006).

In India discrimination is cultural based. The caste system is a race-based classification that is 2500 years old and divided the population into five groups, namely Brahmins, Kshatriyas, Vaisyas, Sudras and Ati-Sudras (Yukondi \& Benson, 2005). The affirmative action programme in India is meant to compensate the lower caste Indians for centuries of discrimination and bring them to the mainstream economy. Unlike the USA, there is no formal mechanism in India to redress noncompliance. The strength of the Indian programme is that it is constitutionally guaranteed and is practically irreversible.

\section{Analysis of the demographic landscape of senior management in South African corporates}

Since democracy in 1994, the South African government has introduced a plethora of legislation and regulation aimed at transformation, enabling previously disadvantaged South Africans full access to all aspects of the economy, including company ownership, share capital and top management positions (Sutherland, 2003). The Commission of Employment Equity was formed by the Department of Labour to monitor implementation of the Employment Equity Act No 55 of 1998. The purpose of this Act is to evaluate compliance based on the mandatory submission by companies who fall under the criteria to submit reports annually.

A broad objective of the Employment Equity Act is to achieve employment for people from designated groups to mirror the Economically Active Population (EAP) numbers. EAP includes all individuals between 15 and 65 who are employed or not employed and seeking employment (Employment Equity Report, 2006). Due to South Africa's historically skewed labour patterns, Africans have the highest population numbers $(79 \%)$, but they are the only group whose EAP lags behind their national figures $(74 \%)$. This is illustrated in Table 1 from the Commission of Employment Equity Report of 2006.

To illustrate the challenge that faces South Africa in its attempt to normalise employment patterns in the labour market, Table 2 illustrates demographics of Black executive and senior managers, as reported by the Employment Equity Report of 2006. Black executive managers are defined as managers who occupy executive directorships in corporate. Black senior managers are defined as managers who are executives and who manage divisions within corporate. Currently, White males occupy $60(2 \%)$ of executive management positions and $51(9 \%)$ of senior management positions, whilst White women occupy 14 (7\%) of executive management positions and $19 \%$ of senior management positions.

Table 3 shows the Employment Equity Report of 2006 and illustrates workplace movement, promotions and recruitment that occurred from the last report of 2004 to the 2006 report. In both senior and executive management, the

TABLE 1: Profile of the national population by race and gender and profile of the economically active population by race and gender.

\begin{tabular}{|c|c|c|c|c|c|c|c|c|c|c|c|c|}
\hline \multirow{3}{*}{$\begin{array}{l}\text { Population } \\
\text { group }\end{array}$} & \multicolumn{6}{|c|}{ National population distribution (Census, 2001) } & \multicolumn{6}{|c|}{ Economically active population (Labour force survey, September 2006) } \\
\hline & \multicolumn{2}{|c|}{ Male } & \multicolumn{2}{|c|}{ Female } & \multicolumn{2}{|c|}{ Total } & \multicolumn{2}{|c|}{ Male } & \multicolumn{2}{|c|}{ Female } & \multicolumn{2}{|c|}{ Total } \\
\hline & $N$ & $\%$ & $N$ & $\%$ & $N$ & $\%$ & $N$ & $\%$ & $N$ & $\%$ & $N$ & $\%$ \\
\hline African people & 16887830 & 37.70 & 15528336 & 41.30 & 32416166 & 79.00 & 6610000 & 39.60 & 5758000 & 34.50 & 1236800 & 74.10 \\
\hline Coloured people & 1920426 & 4.30 & 2074079 & 4.60 & 3994505 & 8.90 & 927000 & 5.50 & 787000 & 4.70 & 1714000 & 10.20 \\
\hline Indian people & 545050 & 1.20 & 570417 & 1.30 & 1115467 & 2.50 & 304000 & 1.80 & 180000 & 1.10 & 484000 & 2.90 \\
\hline White people & 2080734 & 4.60 & 2212905 & 5.00 & 4293639 & 9.60 & 1212000 & 7.30 & 926000 & 5.50 & 2138000 & 12.80 \\
\hline Total & 21434040 & 47.80 & 20385737 & 52.20 & 41819777 & 100.00 & 9053000 & 54.20 & 7651000 & 45.80 & 1670400 & 100.00 \\
\hline
\end{tabular}

Source: Employment Equity Report. (2006). Annual Report, 7th Commission of Employment Equity Report. Pretoria, South Africa: Department of Labour

$N$, used as means of number. 
TABLE 2: Total number of employees by occupational level, race and gender at executive and senior management level.

\begin{tabular}{|c|c|c|c|c|c|c|c|c|c|c|c|c|c|c|c|c|c|c|}
\hline \multirow[t]{3}{*}{ Occupational level } & \multicolumn{8}{|c|}{ Male } & \multicolumn{8}{|c|}{ Female } & \multirow{2}{*}{\multicolumn{2}{|c|}{ Total }} \\
\hline & \multicolumn{2}{|c|}{ African men } & \multicolumn{2}{|c|}{ Coloured men } & \multicolumn{2}{|c|}{ Indian men } & \multicolumn{2}{|c|}{ White men } & \multicolumn{2}{|c|}{ African women } & \multicolumn{2}{|c|}{ Coloured women } & \multicolumn{2}{|c|}{ Indian women } & \multicolumn{2}{|c|}{ White women } & & \\
\hline & $N$ & $\%$ & $N$ & $\%$ & $N$ & $\%$ & $N$ & $\%$ & $N$ & $\%$ & $N$ & $\%$ & $N$ & $\%$ & $N$ & $\%$ & $N$ & $\%$ \\
\hline Executive management & 1282 & 8.4 & 410 & 2.7 & 689 & 4.5 & 9219 & 60.2 & 446 & 2.9 & 310 & 2.0 & 256 & 1.7 & 2250 & 14.7 & 15311 & 100 \\
\hline Senior management & 3206 & 9.8 & 1216 & 3.7 & 1762 & 5.4 & 16922 & 51.9 & 1181 & 3.6 & 699 & 2.1 & 746 & 2.3 & 6182 & 19.0 & 32591 & 100 \\
\hline
\end{tabular}

Source: Employment Equity Report. (2006). Annual Report, 7th Commission of Employment Equity Report. Pretoria, South Africa: Department of Labour

$N$, used as means of number.

TABLE 3: Total number of people recruited, including people with disabilities, by occupational level, race and gender at executive and senior management level.

\begin{tabular}{|c|c|c|c|c|c|c|c|c|c|c|c|c|c|c|c|c|c|c|}
\hline \multirow[t]{3}{*}{ Occupational level } & \multicolumn{8}{|c|}{ Male } & \multicolumn{8}{|c|}{ Female } & \multirow{2}{*}{\multicolumn{2}{|c|}{ Total }} \\
\hline & \multicolumn{2}{|c|}{ African men } & \multicolumn{2}{|c|}{ Coloured men } & \multicolumn{2}{|c|}{ Indian men } & \multicolumn{2}{|c|}{ White men } & \multicolumn{2}{|c|}{ African women } & \multicolumn{2}{|c|}{ Coloured women } & \multicolumn{2}{|c|}{ Indian women } & \multicolumn{2}{|c|}{ White women } & & \\
\hline & $N$ & $\%$ & $N$ & $\%$ & $N$ & $\%$ & $N$ & $\%$ & $N$ & $\%$ & $N$ & $\%$ & $N$ & $\%$ & $N$ & $\%$ & $N$ & $\%$ \\
\hline Executive management & 162 & 17.4 & 47 & 5.1 & 45 & 4.8 & 399 & 42.9 & 79 & 8.5 & 11 & 1.2 & 18 & 1.9 & 99 & 10.6 & 931 & 100 \\
\hline Senior management & 424 & 13.5 & 152 & 4.5 & 177 & 5.6 & 1409 & 44.9 & 164 & 5.2 & 43 & 1.4 & 83 & 2.6 & 581 & 18.5 & 3138 & 100 \\
\hline
\end{tabular}

Source: Employment Equity Report. (2006). Annual Report, 7th Commission of Employment Equity Report. Pretoria, South Africa: Department of Labour

$N$, used as means of number.

most significant recruitments have been of White males (42 [9\%] and $44[9 \%]$, respectively) and White female employees (10 [6\%] and 18 [5\%], respectively).

Table 4 illustrates a trend from the 2000, 2002, 2004 and 2006 Commission of Employment Equity Reports, only at executive management level. White people have made significant gains in the period between 2000 and 2006 (12 [6\%]), although from 2004, their migration to executive management level has declined. From 2004, African people have also shown a decline in executive management growth $(-4 \%)$.

In evaluating the Employment Equity Reports of 2000, 2002, 2004 and 2006, it is clear that true empowerment of African Black senior managers has remained elusive within the South African corporate environment. The status of the implementation of affirmative action programmes does not yet offer Black managers sufficient career paths or succession plans, or even give them enough responsibilities or power over resources (Naidoo, 2005).

\section{Push and pull factors that cause African Black senior managers to leave their organisations}

Literature on factors that cause African Black senior managers to leave organisations is segmented into environmental, organisational and individual factors (Clark \& Kleyn, 2007). Environmental factors are those that exist outside the boundaries of the organisation, including political factors, culture and behaviour, technological changes and economic and legal factors over which the organisation does not have direct control (Cook \& Hunsaker, 2001). Organisational and individual factors are those that are a source of discomfort and push the individual to desire to leave the organisation (Clark \& Kleyn, 2007).

\section{Environmental factors (pull factors)}

The scarcity of top talent in South Africa, especially Black talent, has led to talent retention becoming a major headache for many South African organisations. The changing demographics of the labour market, enduring skills shortages and employee demand for work-life balance have created a so-called war for talent (Alleyne, 2005). Drucker (1994) feels that employees have an upper hand in the workplace as they are seen to hold the tool of trade through their knowledge. As the South African economy has become more service orientated, with the financial services sector contributing $29 \%$ to the Gross Domestic Product (GDP), human skill is pivotal (Booysen, 2005). It thus becomes imperative to have core leadership that has the sound emotional intelligence needed to retain this fluid workforce. Van As (2001) believes that the high mobility of talented workers in South Africa is caused by factors like emigration of skilled workers and equity legislation that cause companies to chase numbers, forcing highly qualified Black talent to be mobile.

Employers must do everything they can to cultivate a powerful, persuasive reputation for talent management if they are to safeguard their long-term talent resources. Large organisations face three challenges. Firstly, a more complex economy requires more sophisticated talent with global acumen, multicultural fluency, technological literacy, entrepreneurial skills and the ability to manage dis-aggregated organisations (Van As, 2001). Secondly, the efficiency of capital markets such as the United States has led to an emergence of a number of small and medium sized companies that are increasingly targeting the same people targeted by large companies. Thirdly, because of the aforementioned two reasons, job mobility is increasing.

TABLE 4: Comparative changes at the top management level from 2000 to 2006.

\begin{tabular}{|c|c|c|c|c|c|c|}
\hline Population group & $2000(\%)$ & $2002(\%)$ & $2004(\%)$ & $2006(\%)$ & Change in \% 2004-2006 & Change in \% 2000-2006 \\
\hline Black people† & 12.7 & 18.4 & 21.1 & 22.2 & 1.1 & 9.5 \\
\hline White people & 87.5 & 81.5 & 78.9 & 74.9 & -4.0 & 12.6 \\
\hline African people & 6.2 & 10.0 & 11.8 & 11.3 & -0.5 & 5.1 \\
\hline Coloured people & 2.7 & 3.4 & 3.7 & 4.7 & 1.0 & 2.0 \\
\hline Indian people & 3.8 & 5.0 & 5.6 & 6.2 & 0.6 & 2.4 \\
\hline
\end{tabular}

Source: Employment Equity Report. (2006). Annual Report, 7th Commission of Employment Equity Report. Pretoria, South Africa: Department of Labour

$\dagger$, Black people refer to African, Coloured and Indian people, as defined by the Employment Equity Act No 55 of 1998. 
Corporate South Africa is desperate for highly skilled Black South Africans to meet their enterprise development and procurement needs. This opportunity has led to a noticeable shift towards having more Black professionals running their own businesses; this requires an appetite for risk, drive, luck and passion. The equity element of Black Economic Empowerment (BEE) is an attraction for talented Black professionals to enter the ranks of entrepreneurs. Entrepreneurs are individuals who recognise opportunities where others see chaos or confusion (Bennett, 2001). The establishment of diversity as a core societal value in post-apartheid South Africa is being implemented by the introduction of laws that enforce corporate transformation. There are legislated requirements for organisations to act as catalysts for developing designated employees who were under-developed during the apartheid era (Mazola, 2001). The Employment Equity Act No. 55 of 1998 and other legislation like the Skills Development Act and Broad Based Black Employment Equity (BBBEE) have legislated that employers need to achieve set targets in terms of their different levels of management to employ, train and develop Black senior managers. These laws are also supported by the national constitution, which affords equal status to all racial and cultural groupings, languages and religious groupings (Thomas \& Ely, 1996).When employment equity is managed from the perspective of diversity management, it is less divisive than when managed from the affirmative action perspective (Derrick, 2005).

\section{Organisational and individual factors (push factors)}

Scarcity of mentorship in organisations is an acknowledged driver of voluntary turnover (Campbell \& Alleyne, 2002; Payne \& Huffman, 2005). Rentilla (2006) found that when colleagues in cross-race mentoring relationships shared complementary racial perspectives (common attitudes about race and race related issues), their relationship evolves into rewarding mentor-protégé relationships. A problem that may exist for Black managers is the lack of mentors. Companies that employ formal mentorship and coaching programmes can assist people in becoming a part of the in-group, thus encouraging their retention (Woolnough \& Davidson, 2007). Experienced managers are at times reluctant to take on mentoring, either because they are insecure or because they are unwilling to train and develop young talent without an economic incentive for them to do so.

Employers have to be aware of the psychological contract between the employer and the employee. The psychological contract essentially refers to the mutual expectations people have of one another in a relationship, and how these expectations change and influence our behaviour over time (Rousseau, 2004). A significant consequence of the change in the psychological contract is the increased mobility of knowledge workers (Sutherland, 2003). Globally, employment relations have changed dramatically over the last decade, with Harris and Brannick (1999) indicating that the turbulent business environment has changed the relationship between employer and employee from a strong long-term connectivity type relationship to one of short-term instability and disconnection. African Black senior managers manage their careers and will commit to an organisation as long as their career goals are met.

Booysen (2007) states that inter-group anxieties and tensions exist because they have built up over time due to apartheid's discriminatory legislation and the transformation efforts to redress this. Booysen (2005) claims that these tensions have given rise to three social identities in the South African workplace, namely African Black people, White men and a 'middle group' consisting of White women, Coloured people and Indian people. Often African Black people are frustrated by the perceived slow pace of transformation. Sutherland (2003) states that Black employees want clarity on the psychological contract with their employers and for their loyalty, they will expect continuous professional development as well as exposure to higher decision-making roles.

Job satisfaction has an impact on African Black senior managers' decision making process to stay or leave organisations. Herman and Gioia (2000) states that job satisfaction can be described as a global feeling about the job or a related constellation of attitudes about various facets or aspects of the job. Job satisfaction and organisational commitment have been found to be both inversely related to such withdrawal behaviours, such as tardiness, absenteeism and turnover (Hay, 2001). Trevor (2001) found that if employees are satisfied with their work, they would show greater commitment. Conversely, dissatisfied workers with negative attitudes will leave the organisation. The nature of work performed by employees has a significant impact on their level of satisfaction (Light, 2005). Kaliprasad (2006) found financial rewards to have a significant effect to job satisfaction.

A corporate culture is the cement that binds a corporation together; however, it also excludes others (Thomas \& Ely, 1996). In South Africa, the economy is still controlled by English-speaking conglomerates although the workforce remains predominantly African Black (Thomas \& Bendixen, 2000). The structure of the South African economy's management has led to a Euro-centric culture that advocates individualism, competition and an Afro-centric culture that advocates inclusiveness and solidarity. According to Prime (1999), positive traits are attached to the 'in-group' and negative traits to the 'out-group'. According to Prime, the style of management in South Africa is still autocratic (man-in-charge), authoritarian and hierarchical (disciplinary procedures), and individualistic (competitive). The traditional Western culture of competing limits a sharing of knowledge and ideas. Gillis, Gomes, Valliere and Doyne (2001) argue that Black employees are generally still seen as:

- lacking assertiveness

- lacking initiative

- having no work ethic ('Africa time')

- an unproductive culture

- prone to communism 
- having lower standards and higher fault tolerance

- having unrealistic expectations and chaotic education.

The majority of South African businesses are based on Western cultural norms and Black people traditionally have been excluded in the majority of economic life. Historically Black people have been deprived of decision making in any part of the production process, hence they have been indifferent to productivity (Maharaj, 2003). Horwitz, Jain and Mbabane (2002) argue that transformation has left some White managers and employees with emotions of stress, denial, mistrust and resistance to new ideas. A potential negative outcome of this concern is that government's transformation agenda may not be a top priority for many organisations, this law may be reduced to a matter of legal compliance driven by senior corporate leadership of the employment equity office.

Reaction to employment equity legislation differs amongst the different race groups. Some beneficiaries (i.e. Black Africans, Coloured and Indian people) share concerns, including being sell-outs, being sold out and being victims of White manipulation, victimisation tokenism and marginalisation when appointed as employment equity (EE) candidates (Atkinson, Coffey \& Delamont, 2003). Many employment equity beneficiaries dislike being labelled as tokenism beneficiaries; they believe in career advancement because of individual merit. Conversely, many White people fear retribution and/or revenge from non-White people, loss of standards, punitive taxation and nationalisation and they tend to question the ethical and political legitimacy of this policy (Derrick, 2005).

There is solid evidence that compensation decisions affect business performance (Bussin, 2003; Gerhart, 2000). Remuneration has become one of the most important levers in attracting and retaining tale summed up by the question: 'How does an employer motivate employees?' (Hertzberg, Mausner \& Snyderman, 1957). Pay remains the most powerful motivator of results. Human capital theory states that, other things being equal, a worker will have a greater probability of leaving a low paying job than a higher paying one (Huang, Lin \& Chuang, 2006). A failure to build social networks has also been associated with increased voluntary turnover because of exclusion (Pini, Brown \& Ryan, 2004; Simpson, 2000). Poor managerial quality is also associated with an employee's decision to leave (Campbell \& Alleyne, 2002). Although managerial quality manifests as an organisational factor, the individual's ability to deal with this is also important.

\section{Research design \\ Research approach}

The research was conducted in two phases, a qualitative study and a quantitative study. Creswell (2003) refers to this approach as triangulation. This approach is a sequential and less-dominant design. For the qualitative study, a particular social reality could be investigated, analysed and interpreted differently depending on the researcher's belief of what social reality is (ontology) and how social phenomena can best be known (epistemology) (Potter, 1996). A primary purpose of the qualitative part of this research was to verify constructs identified in literature review and fine tune the questionnaire.

For the quantitative study, which was phase two, deductive reasoning was used as explained by Creswell (1994). The quantitative research was done utilising primary data of a numerical nature. A wide range of descriptive bivariates and multivariates statistical analysis were performed on the data. Terre Blanche, Durrheim and Painter (2007) define research design as a strategic framework that guides the researcher into causing the research questions to be operational.

\section{Research method}

\section{Research participants}

For the qualitative study, the research was conducted in Gauteng utilising five financial services companies. These companies' head offices are based in Johannesburg and Pretoria and they include banks as well as life insurance companies. Five participants out of a pool of 40 African Black senior managers per organisation were selected, which was representative, and the inputs saturated.

The questionnaire was developed from the literature review and then piloted with five human resources experts. Appropriate suggestions were taken into account and the questionnaire was amended accordingly. The questionnaire was then sent to the Human Resources corporate member representatives in the South African Rewards Association, 21st Century Business and Pay Solutions, one of the largest reward consultancies in South Africa and members of the Association of Black Actuaries and Investment Professionals (ABSIP). The representatives forwarded the survey to a stratified sample of 2600 employees to complete the questionnaire on an anonymous basis. A total of 208 responses were received from the participants. This represents a response rate of $8 \%$. The respondents are reflected in Table 5, categorised into five categories.

Male and female respondents were relatively evenly distributed with male respondents forming $60.9 \%$ of the sample.

The majority of respondents were between 31 and 40 years of age which ties in with most respondents being in senior management.

The executive and senior management category was $71.1 \%$ of the sample.

The producer services sector was $30.8 \%$ of the sample reflecting a slight dominance from the financial services sector.

Respondents who earned more than R545 000.00 per annum constituted $66.3 \%$ of the sample. 


\section{Measuring instruments}

Questionnaires are typically used to collect perceptions (Denscombe, 2007).The questionnaire was designed from two sources. Firstly, information was gathered through the literature review. Secondly, the qualitative interviews from phase one provided further input by validating the variables. STATKON, the University of Johannesburg's statistics department provided further guidelines to ensure an effective factor analysis could be performed. STATKON recommended that the questionnaire have 30 constructs in order to have an effective factor analysis. The questionnaire had three sections. Section A contains demographic questions that are the stated demographic variable in the study. The demographic data collected through the questionnaire was used as it covered all the demographic variables identified. Section B evaluated the length of service in the previous organisation and the level of satisfaction. The objective was to determine whether tenure of service has any correlation with the level of satisfaction. The respondents were asked to complete Schriesheim and Tsui's (1980) Job Satisfaction Index on a 7-point adapted Likert-type scale, completing a questionnaire with 30 items. Section $C$ lists the 30 items that were derived from a thorough literature review and the qualitative interview. The respondents had to indicate how they had experienced various aspects of their work in their immediate previous company in relation to the 30 items. The Likert-scale used ranged from 1 ('Never') to 7 ('Always').

\section{Research procedure}

The electronic link was included in the mail sent to the potential respondents. The link was uniquely encoded to ensure that the respondents could be identified for purposes of this study. Ten days after the closing date, STATKON, through the Head of Department, University of Johannesburg, provided Excel spreadsheets with detailed information on all the categories that were in the questionnaire. The data was analysed utilising the SPSS statistical package and converting it into an Excel format.

\section{Statistical analysis}

For the qualitative study, I analysed the data using the field notes, focusing on similarities and differences in the views of the research participants. Once patterns and themes were derived, I compared these with concepts of incentive schemes, motivation theory and performance extracted from the literature. Statistical analysis was applied to the questionnaire, which comprised three sections as described earlier. Statistical inference generalises about the sample from which it was taken by using descriptive statistics (Steyn, Smit, Du Toit \& Strasheim, 2000). The relationships between the variables were assessed by the following statistical methods. Descriptive statistics were used on Section A results to analyse the demographic data and to understand the characteristics of the sample group. Percent and frequencies were used for analysis. The five job satisfaction work elements of satisfaction were recorded utilising the 7-point Likert scale, from 'Very dissatisfied' to 'Very Satisfied' for Section B. A principle component factor analysis was done on the results obtained from the questionnaire. Kaiser-Meyer-Olkin measure of sampling adequacy indicated whether the items used in the questionnaire could be grouped into categories for purposes of populating the retention model. Bartlett's test of sphericity assesses the assumption of sphericity of the data. The test tends to be sensitive in detecting the correlations amongst the dependent variables (Morgan, Reichert \& Harrison, 2002). Results on Bartlett's test of sphericity should be significant $(p<0.05)$ to be considered appropriate (Pallant, 2007).

\section{Results}

The specific aspects explored in this survey were the reasons why African Black senior managers leave their organisations. A synopsis of the biographical data is reflected in Table 5 to Table 9 in the previous section. The main finding and contribution to this field of study was that African Black senior managers do not trust organisations with their career development. They would rather take control of their own career development by moving from organisation to organisation to build their repertoire of skills and competence.

TABLE 5: Characteristic one: Gender of respondents.

\begin{tabular}{lcc}
\hline Gender & Frequency & $\mathbf{\%}$ \\
\hline Male & 126.0 & 60.9 \\
Female & 82.0 & 39.1 \\
\hline Total & $\mathbf{2 0 8}$ & $\mathbf{1 0 0}$ \\
\hline
\end{tabular}

TABLE 6: Characteristic two: Age of respondents.

\begin{tabular}{lcc}
\hline Age & Frequency & $\mathbf{\%}$ \\
\hline Less than 25 years & 2.0 & 1.0 \\
26 to 30 years & 26.0 & 12.5 \\
31 to 40 years & 124.0 & 59.6 \\
41 to 50 years & 9.0 & 4.3 \\
Above 50 years & 47.0 & 22.6 \\
\hline Total & $\mathbf{2 0 8}$ & $\mathbf{1 0 0}$ \\
\hline
\end{tabular}

TABLE 7: Characteristic three: Management level of respondents.

\begin{tabular}{lcc}
\hline Management level & Frequency & $\mathbf{\%}$ \\
\hline Senior management & 82.0 & 39.4 \\
Executive manager & 66.0 & 31.7 \\
Director & 29.0 & 13.9 \\
Chief executive officer & 18.0 & 8.7 \\
Other & 13.0 & 6.3 \\
\hline Total & $\mathbf{2 0 8}$ & $\mathbf{1 0 0}$ \\
\hline
\end{tabular}

TABLE 8: Characteristic four: Industry sector type affiliation of respondents.

\begin{tabular}{lcc}
\hline Industry sector and type & Frequency & $\mathbf{\%}$ \\
\hline Distributive services & 26.0 & 12.5 \\
Producer services & 64.0 & 30.8 \\
Personal services & 57.0 & 27.4 \\
Logistics and transport & 31.0 & 14.9 \\
Social services & 23.0 & 11.1 \\
Other & 7.0 & 3.4 \\
\hline Total & $\mathbf{2 0 8}$ & $\mathbf{1 0 0}$ \\
\hline
\end{tabular}

TABLE 9: Characteristic five: Income categories of respondents.

\begin{tabular}{lcc}
\hline Income categories & Frequency & \% \\
\hline R303 000.00 to R544 999.00 & 70.0 & 33.7 \\
Above R545 000.00 & 138.0 & 66.3 \\
\hline Total & $\mathbf{2 0 8}$ & $\mathbf{1 0 0}$ \\
\hline
\end{tabular}


They want to be in charge of their careers. This finding has profound implications for organisations employing African Black managers in the senior cadre. This finding is consistent with the findings of the qualitative interviews.

The following secondary findings were discovered, with actual comments from respondents:

- Respondents were happy with their peers and the nature of their work:

'The most wonderful part of my job was the support I received from my team and practising my passion of analysing financial markets.'

- They were, however, dissatisfied with their immediate line manager, pay and advancement opportunities:

'Remuneration was not market related.'

'The most frustrating part was that I could not see where my career was going.'

'I left my job because of my line manager; he did not support advancement of blacks.'

- Career management, quality leadership from immediate manager, the desire to be an entrepreneur and ethical behaviour of the company were important:

'I partnered with a friend of mine to be a BEE partner in a mining transaction.'

'I could not morally reconcile with the effects of our product, alcoholic beverages, within the townships, I could not sleep well because of that and I decided to leave.'

'My manager was reactive in supporting my career.'

'I am the CEO of my career and when I could not achieve my goals within my company, I decided to seek other pastures.'

- Mentorship, discrimination, being sabotaged and a culture of diversity were not of utmost importance:

'White colleagues that were junior to me, had better privileges like better desks, computers.'

'I did not trust my colleagues and felt I was being set up for failure all the time.'

'There was no mentorship.'

In the analysis of the qualitative interview responses, the main desire around career was being presented with career advancement opportunities, although a few respondents also highlighted external push factors of starting their own business. On the work theme, excessive travelling which impacted on work-life balance was also an issue. With regard to management, lack of vision and unsupportive managers were a challenge. Dissatisfaction with pay ranged from lack of variable pay to pay not being market related. There was also a strong perception that line managers were not supportive of transformation. Some respondents stated incidents of White colleagues being treated better than Black colleagues are.

In Table 10 is a ranking of the 10 most important variables that create propensity to leave, arranged by mean.

Table 10 shows the most important variables that contribute to the mobility of African Black senior managers, ranked by mean. The top 10 variables reveal a number of interesting themes. The first theme focuses on taking ownership of one's own career and the possibility of pursuing entrepreneurship opportunities, as revealed by variables ranked one and three. It appears that there is a strong need for a strong locus of control. These pull factors could be influenced by the BBBEE legislation and associated codes, which have disrupted the labour market.

Table 11 shows a ranking of the 10 least important variables that create propensity to leave when arranged by mean.

Table 11 illustrate the least important variables that contribute to the mobility of African Black senior managers. The bottom 10 variables also reveal a number of interesting themes. There are two themes, with the first theme revealing that the respondents did not leave the employer because they were feeling sabotaged in the workplace, shocking events, or experiencing discrimination as revealed by variables one, six and seven. This creates hope that in spite of White employees feeling threatened by BBBEE employment equity practices in their workplace, their behaviour is now normalised and there is little overt discrimination at management level. The two race issues in theme three are about very subtle aspects to diversity management and not the overt aspects reported in this theme.

The second theme reveals that the senior Black managers were not bothered with the fact that they were not getting the enabling corporate support they expected in their psychological contract with the organisation. The item intercorrelation was subjected to a Kaiser-Meyer-Olkin (KMO) test and a Bartlett's test, and was 0.764 which is higher than 0.7 making the matrix suitable for being factor analysed. Two factor analytic methods were used to determine the four

TABLE 10: The most important variables that drive mobility.

\begin{tabular}{lll}
\hline Rank & Variable & Mean \\
\hline 1 & Managing own career direction & 5.26 \\
2 & $\begin{array}{l}\text { White managers and their personal fear about Black } \\
\text { Economic Empowerment }\end{array}$ & 4.85 \\
3 & Desire to be an entrepreneur & 4.69 \\
4 & Lack of leadership from immediate manager & 4.43 \\
5 & Company behaving ethically & 4.43 \\
6 & Commitment to career than organisation & 4.42 \\
7 & Experience of company as professional & 4.15 \\
8 & Intention to leave the organisation & 4.12 \\
9 & Feeling of glass ceiling & 4.06 \\
10 & Lack of proximity to decision makers & 4.01 \\
\hline
\end{tabular}

TABLE 11: The least important variables that drive mobility.

\begin{tabular}{lll}
\hline Rank & Variable & Mean \\
\hline 1 & Experience of a shocking work incident & 3.27 \\
2 & Career development opportunities & 3.26 \\
3 & Company attracting and retaining staff & 3.26 \\
4 & Being appointed for Employment Equality compliance & 3.23 \\
5 & Expectation of immediate promotion & 3.18 \\
6 & Being sabotaged & 3.06 \\
7 & Experiencing discrimination in the work place & 2.96 \\
8 & Culture of diversity being managed & 2.92 \\
9 & Presence of mentoring and coaching & 2.82 \\
10 & Company owing opportunities due to Employment & 2.54 \\
\hline
\end{tabular}


factors, which are used in the research. Firstly, the extraction method was the Principal Axis Factoring and secondly, with Varimax techniques of rotation. Normalisation was used as a rotation method. It was determined that the Cronbach alpha was 0.721 and therefore the scale was not reliable.

During the analysis, five Eigen-values (5.716; 2.659; 2.179 ; 1.703 and 1.519) were identified, which accounted for $45.9 \%$ of the variance. To compare the empirical research with the theory, a 5-factor analysis was forced. The outcome is reflected in Table 12. The communalities of the variables are determined for the first number of factors. This procedure is repeated until the sum does not change (Giorgi, 1985).

A cluster analysis was conducted in order to explore the data set for subgroups of homogeneous individuals (Atkinson et al., 2003). After a visual inspection of the 30 items, the three clusters that were derived were identified and labelled as 'content', 'downtrodden' and 'silent soldier'. The content subgroup included individuals who were generally very satisfied and were in executive management. The downtrodden subgroup included individuals who were generally very dissatisfied and were mainly in senior management and middle management. The silent soldier subgroup included individuals who were generally satisfied but the organisation did not realise and utilise the commitment these individuals showed.
In the quantitative questionnaire there was an open-ended question that requested the respondents to list any other factors that might have influenced their decision to leave their last employer. This question elicited rich data from 122 respondents. Tables 13,14 and 15 depict an analysis of the responses from phase two participants across the three clusters. Content analysis was applied similar to the phase one qualitative data analysis. The five themes utilised in phase one were also utilised in analysis of phase two openended questions. The themes were utilised on feedback received by the three subgroups identified in cluster analysis. The themes were career, discrimination, management, pay and work.

\section{Discussion}

The main objective of this research is to understand factors that will push and pull African Black senior managers to explore opportunities outside their organisations. The main contribution of the study is that it will assist executive managers to create a corporate environment that will promote a sense of belonging amongst African Black senior managers, leading to lower labour turnover. Further contribution of this research is to improve retention of African Black senior managers, which will have a greater positive effect in the organisation in that retention is improved, a better understanding of diversified employee segments is achieved, social transformation imperatives in the country are

TABLE 12: First-order factor analysis: Factor matrix.

\begin{tabular}{|c|c|c|c|c|c|}
\hline \multirow[t]{2}{*}{ Items } & \multicolumn{5}{|c|}{ Factor } \\
\hline & 1 & 2 & 3 & 4 & 5 \\
\hline Individual recognition and praise given & 0.702 & - & - & - & - \\
\hline Mentorship and coaching & 0.540 & - & - & - & - \\
\hline Feeling of leaving the organisation & 0.532 & - & - & - & - \\
\hline Experience of company as professional & 0.526 & - & - & - & - \\
\hline Being part of the corporate culture & 0.508 & - & - & 0.373 & - \\
\hline Lack of leadership from immediate manager & 0.473 & - & - & - & - \\
\hline Own career goals aligned to company goals & 0.438 & 0.400 & - & - & - \\
\hline Company behaving ethically & 0.330 & - & - & 0.309 & - \\
\hline Job stimulation & - & 0.575 & - & - & - \\
\hline Closeness to decision makers & 0.307 & 0.566 & - & - & - \\
\hline Freedom to work independently & - & 0.509 & - & - & - \\
\hline Company set to attract and retain talent & - & 0.453 & - & - & - \\
\hline Satisfaction with own remuneration package & - & 0.449 & - & - & - \\
\hline Being judged on skin colour than as an individual & - & - & 0.658 & - & - \\
\hline Experience of discrimination in the workplace & - & - & 0.649 & - & - \\
\hline Being sabotaged & - & - & 0.566 & - & - \\
\hline White managers' fear about Black Economic Empowerment & - & - & 0.442 & - & - \\
\hline Owed opportunities by company due to Employment Equity Act & - & - & 0.403 & - & - \\
\hline Being appointed only for Employment Equity Act compliance & - & - & 0.343 & - & -0.311 \\
\hline Job promotion expectations & - & - & 0.340 & - & - \\
\hline Management of own career direction & - & - & - & 0.512 & - \\
\hline Commitment to own career than the organisation & - & - & - & 0.430 & - \\
\hline Work and personal life balance & - & - & - & 0.430 & - \\
\hline Experience of a shocking work incident & - & - & - & 0.414 & - \\
\hline Glass ceiling reached & - & - & 0.356 & - & 0.475 \\
\hline Being left alone to implement decisions & - & - & - & - & -0.455 \\
\hline Limitations on Employment Equity progress & - & - & - & - & -0.451 \\
\hline
\end{tabular}




\begin{tabular}{lll}
\multicolumn{2}{l}{ TABLE 13: Content cluster of individuals. } \\
\hline Theme & Number of responses & Percentage of responses \\
\hline Career & 18.0 & 48.6 \\
Discrimination & 2.0 & 5.4 \\
Management & 8.0 & 21.6 \\
Pay & 1.0 & 2.7 \\
Work & 8.0 & 21.6 \\
\hline Total responses & $\mathbf{3 7}$ & $\mathbf{1 0 0}$
\end{tabular}

TABLE 14: Downtrodden cluster of individuals.

\begin{tabular}{lll}
\hline Theme & Number of responses & Percentage of responses \\
\hline Career & 14.0 & 25.9 \\
Discrimination & 5.0 & 9.3 \\
Management & 18.0 & 33.3 \\
Pay & 5.0 & 9.3 \\
Work & 12.0 & 22.2 \\
\hline Total responses & $\mathbf{5 4}$ & $\mathbf{1 0 0}$ \\
\hline
\end{tabular}

TABLE 15: Silent soldier cluster of individuals.

\begin{tabular}{lll}
\hline Theme & Number of responses & Percentage of responses \\
\hline Career & 15.0 & 48.4 \\
Discrimination & 1.0 & 3.2 \\
Management & 5.0 & 16.1 \\
Pay & 4.0 & 12.9 \\
Work & 6.0 & 19.4 \\
\hline Total responses & $\mathbf{3 1}$ & $\mathbf{1 0 0}$ \\
\hline
\end{tabular}

addressed and a diversified voice in corporate boardrooms bringing different perspectives is present.

\section{Results are discussed in relation to research objectives}

\section{Factors that push and pull African Black senior managers} to explore outside opportunities

Content analysis of phase one interviews shows that a number of African Black senior managers who mentioned perceptions of discrimination from their immediate manager, also mentioned lack of support from the immediate manager. Some went further to highlight a lack of values and lack of leadership skills on the part of. The other group of African Black senior managers is the one that leaves because of inadequate career opportunities. A deficiency of advancement opportunities often propels executives to leave the organisation as Mainiero and Sullivan (2005) found. The findings of this research concur with Drucker's (1994) research, which showed that independence, individualism and personal achievement are the fundamental needs of African Black senior managers and other workers in general. Drucker stated that retention strategies should be based on the freedom to act, financial rewards and recognition, development opportunities and access to leading technologies. African Black senior managers want to be able to trust management - Harpur (2002) is the only other author who has mentioned this critical component of African Black senior managers - and to have a good relationship with their immediate manager.

In South Africa entrepreneurship often starts at the back of government's policies designed to support its growth, with opportunities in the procurement of goods for government projects and consumption. African Black senior managers take control of their own career development by moving from organisation to organisation to build their repertoire of skills and competence. They want to be in charge of their careers.

\section{The demographic composition of senior management and top management}

The racial composition of senior and top management as reported by the Employment Equity Report of 2006 is a challenge that has to be reversed. The challenges of senior and top management being composed mainly of one gender and one race, can limit diversity, increase animosity as indicated in the results of the study, where African Black senior managers perceive senior management positions to be inaccessible to them.

\section{International literature: Similarities and differences in transformation challenges and solutions}

International comparison is more relevant between South Africa and the USA. Whilst employment equity is legislated in South Africa, it is not legislated in the USA. The USA has been managing a paradox between maintaining meritocracy and achieving equity in its workforce. After 40 years of employment equity measures implementation, the results are not positive with the workforce being mainly White male. The USA case study affords South Africa an opportunity to proactively realise pitfalls in the USA employment equity legislation.

\section{Literature review integration with the findings}

The participants state that they are expected to fit in. This phenomenon was identified by Rigdon and Hymowitz (1992) who argue that Black executives who have acquired Master of Business Administration degrees (MBAs), corporate titles and comfortable incomes appear to have it made but in reality, they walk a very tight rope in the corporate world where they are expected to blend in with a culture that never fully accepts them. Sutherland (2003) argues that remuneration is not linked to either job satisfaction or to organisational commitment, and that share options tend to have a greater impact on retention than pay. Results confirmed this view with respondents stating that there was no variable pay or they felt that there was no parity in pay with the market. The findings of this research concur with Drucker's (1994) research, which showed that independence, individualism and personal achievement are the fundamental needs of African Black senior managers and other workers in general. African Black senior managers want to be able to trust management - Harpur (2002) is the only other author who has mentioned this critical component of African Black senior managers - and to have a good relationship with their immediate manager. This is in agreement with Mainiero and Sullivan (2005) who asserted that an employee's stay in an organisation is determined by their relationship with the immediate manager. 


\section{Recommendations and implications \\ To management}

Line managers and senior human resources managers in particular need to understand that:

- Realistic and transparent discussions with each employee on perceived potential within an organisation.

- Retention means that organisations must develop competency in attracting and selecting highly competent African Black senior managers and ensure continual transfer and encoding of knowledge so that empowerment of the individual is achieved. Organisations need to understand who their best employees are, what their employees want and need, ensure that they get it and make sure they know they are getting it. An aligned employee value proposition will ensure an employee is afforded challenging work, there are development opportunities and rewards are based on individual performance.

\section{To African Black senior managers}

They need to consider that:

- This is the age of self-determination. They need to continuously create their own future by developing themselves and focused on labour market related competencies.

- Awareness of their own retention cognitions will assist them to achieve a better match with organisations when they seek employment.

- They have to conduct enough research on the job market realities and their potential new function; evaluate their new employer's financial stability and the job description that accurately reflects the job title; ensure that there is a cultural fit between themselves and the new organisation; and they should not change jobs purely based on a financially attractive package offer.

- They have to plan their next career move and should not be pre-occupied with trying to get away from a current employer because they are dissatisfied. African Black senior managers must search and wait for the right offer.

- Groysberg and Abrahams (2010) state that people at times believe that they contribute more than they actually do and as such, undervalue the strength of their organisation in helping them to achieve their objectives. African Black senior managers should realistic about their personal strengths and weaknesses and should not have an overly optimistic view of themselves.

- The best protection against career management mistakes is a sense of self-awareness. This entails being aware of one's career relevant strengths and weaknesses, as well as how to correct these mistakes. It is a good idea to have a mentor, who can be a reflection on how others perceive one, and discusses and exchange ideas on what elements of a job are satisfying to one and what constitutes a healthy work-life balance. Look for industries where your skills represent a genuine asset.

- It is strategic to join an eminent company early in one's career. There is an inclination to equate brand names with skills and knowledge.

\section{Conclusion}

The most profound findings were that career development is the focus of African Black senior managers. Wealth creation through entrepreneurship is also important. As a conclusion, if organisations are to retain African Black senior managers, they will need to create an environment that enables an African Black senior manager to advance their career and have transparent discussions with them relating to their cognitive abilities, whilst also creating opportunities for them to build equity. Recommendations to African Black senior managers in particular are that they need self-awareness to be aware of their limitations and strengths and manage their career aspirations accordingly. The researcher believes that the main research and secondary objectives have been achieved.

\section{Limitations of this research}

There was limited literature focusing on the mobility of African Black senior managers. The available literature mainly concentrates on the USA. The USA was one of the first countries to implement affirmative action more than 40 years ago. The questionnaires were distributed to employees working in mainly large corporate companies and therefore the results could be skewed towards the views of employees working within large corporate companies as opposed to, for example, the government sector. Generalisation of results should therefore be done with the required caution. The results of the factor analysis were not adequate. Based on this cluster analysis was performed.

\section{Future research}

Other researchers may want to research the following topics:

- In South Africa, a country where the Employment Equity Act has disrupted the labour market positively or negatively, further research could be done in terms of the impact on other levels of management and general employment, which has not been the focus of this study.

- Studies will have to be done on companies that have been successful in retaining African Black senior managers, so that their employee value propositions can be understood and shared.

- Research on White management's perception of the Employment Equity Act will have to be undertaken. This is critical in understanding how White managers view and treat Black employees who report to them.

\section{Acknowledgements Competing interests}

The authors declare that they have no financial or personal relationship(s) which may have inappropriately influenced them in writing this paper.

\section{Authors' contributions}

K.N. was responsible for experimental and project design. M.B. made intellectual and conceptual contributions. K.N. and M.B. wrote the manuscript. 


\section{References}

Allen, D.G., \& Griffith, R.W. (1999). Job performance and turnover: A review and integrative multi-route model. Human Resource Management Review, 9(4), 525548. http://dx.doi.org/10.1016/S1053-4822(99)00032-7

Alleyne, S. (2005). Is being the best good enough? New York City: Earl G. Graves Publishing Co., Inc.

Atkinson, P., Coffey, A., \& Delamont, S. (2003). Key themes in qualitative research. California: Altamira Press.

Bennett, J. (2001). Employers have their work cut out. Johannesburg: Johnnic Publications Company.

Berger, L.A., \& Berger, D.R. (2004). The talent management handbook. United States of America: The McGraw Hill Companies.

Booysen, L. (2005). Social identity changes in South Africa: Challenges facing leadership. Lecture at the Gordon Institute of Business Leadership, University of Pretoria, lllovo.

Booysen, L. (2007). Societal power shifts and changing social identities in South Africa: Workplace Implications, Submitted for publication. Southern African Journal for Economic and Management Sciences, 10(1), 1-20.

Bussin, M. (2003). Factors driving changes to remuneration policy and outcomes. Unpublished doctoral thesis, University of Johannesburg, Johannesburg, South Unpublish.

Campbell, B., \& Alleyne, S. (2002). The High Cost of Turnover. Black Enterprise, 33(5), 61.

Census. (2001). Primary tables South Africa. Report No. 03-02-04 (2001). South Africa: Statistics South Africa.

Clark, D., \& Kleyn, N. (2007). Why they leave? Unpublished master's thesis, University of Pretoria, Pretoria, South Africa.

Cook, C.W., \& Hunsaker, P.L. (2001). Management and organisational behaviour. (3rd edn.). International Edition. Boston: McGraw-Hill Irwin.

Creswell, J.W. (1994). Research design: Qualitative \& quantitative Approaches. London: Sage Publications Inc.

Creswell, J.W. (2003). Research design. London: Sage Publications Inc.

Czakan, P. (2006). Retention of workers in telecommunications. Unpublished MBA thesis, University of Cape Town, Cape Town, South Africa.

Denscombe, M. (2007). The Good research guide for small-scale social research projects. England: Open University Press.

Derrick, S. (2005). Reward tactics. Promotions \& Incentives, Jul/Aug, 44-48.

Drucker, P.F. (1994). They're not employees, they're people. Harvard Business Review, February, 70-77.

Employment Equity Report. (2006). Annual Report, 7th Commission of Employment Equity Report. Pretoria, South Africa: Department of Labour.

Gerhart, B. (2000). Compensation strategy and organisational performance. In S. Rynes \& B. Gerhart (Eds.), Compensation in Organisations (pp. 151-194). San Francisco: Jossey-Bass.

Gillis, R.E., Gomes, R., Valliere, P., \& Doyne, J. (2001). The politics of affirmative action, University of Rhodes Island, Office of Affirmative Action, Equal Opportunity and Diversity, United States of America.

Giorgi, A. (1985). Phenomenology and psychological research. Pittsburgh: Duquesne University Press.

Groysberg, B., \& Abrahams, R. (2010). Five Ways to Bungle a Job Change. Harvard Business Review, January-February, 137-140.

Hamori, M. (2010). Job Hopping to the Top and Other Career Fallacies. Harvard Business Review, July-August, 154-157.

Harpur, A. (2002). Retention factors affecting knowledge workers in the financia services sector. Unpublished MBA project report, University of the Witwatersrand, Johannesburg, South Africa.

Harris, J., \& Brannick, J. (1999). Finding and keeping great employees. New York: American Management Association.

Hay, M. (2001). Strategies for survival in the war of talent. Career Development International, 7(1), 52- 59. http://dx.doi.org/10.1108/13620430210414883

Herman, R.E., \& Gioia, J.L. (2000). How to become an employer of choice. United States of America: Oakhill Press.

Hertzberg, F., Mausner, B., \& Snyderman, B. (1957). The motivation to work. New York: Wiley.

Horwitz, F.M., Jain, H., \& Mbabane, L. (2002). Trade union consultation by employers under Employment Equity legislation. South African Journal of Labour Relations, 29(2-4), 4-32.

Huang, I., Lin, H.C., \& Chuang, C.H. (2006). Constructing factors related to worker retention. International Journal of Manpower, 27(5), 491-508. http://dx.doi. retention. International Journal of
Johnson, M. (2000). Winning the people wars: Talent \& the battle for human capital. London: Prentice-Hall.

Kaliprasad, M. (2006). Attracting, retaining and motivating capable people. Cost Engineering, 48(6), 20-26.

Labour Force Survey. (2006). Handbook for Census Management for Population and Housing Censuses, Series F, No. 83. South Africa: Statistics South Africa.

Lamb, M. (2007). The components of career capital for knowledge workers in a global economy. Unpublished MBA thesis, University of Pretoria, Pretoria, South Africa.

Lehohla, P. (2005). Census 2001: Stages in the life cycle of South Africans. Report No. 03-02-46. South Africa: Statistics South Africa.

Light, A. (2005). Job Mobility and Wage Growth: Evidence from the NLSY79. Monthly Labour Review, 128(2), 33-39.

Maharaj, K. (2003). A comparative study of the psychological contract of white and black managers, Unpublished research report, University of the Johannesburg, Johannesburg, South Africa.

Mainiero, L.A., \& Sullivan, S. (2005). Kaleidoscope Careers: An Alternate Explanation for the 'Opt-out' Revolution. Academy of Management Executive, 19(1), 106-123. $\mathrm{http} / / / \mathrm{dx}$.doi.org/10.5465/AME.2005.15841962

Mazola, S. (2001). The effect of Apartheid on development of Africans. Unpublished MA report, University of South Africa, Pretoria, South Africa.

Morgan, S.E., Reichert, T., \& Harrison, T.R. (2002). From numbers to words. United States of America: Pearson Education.

Naidoo, A. (2005). The current importance of affirmative action in the automotive industry. Unpublished MA thesis, University of Pretoria, Pretoria, South Africa.

Ngambi, H.C. (2002). The role of emotional intelligence in transforming South African organisations. International Economic and Management Sciences Conferences, (pp. 221-231). Vaal Triangle Technikon, Vanderbijlpark, South Africa.

Pallant, J. (2007). SPSS Survival manual. (3rd edn.). Glasgow: Bell \& Bain Ltd.

Payne, S., \& Huffman, A.H. (2005). A Longitudinal Examination of the Influence of Mentoring on Organisational Commitment and Turnover. Academy of Management Journal 48(1), 158-168. http://dx.doi.org/10.5465/AMJ.2005.15993166

Pini, B., Brown, K., \& Ryan, C. (2004). Women-only Networks as a Strategy for Change? A case from Local Government. Women in Management Review, 19(5/6), 286292. http://dx.doi.org/10.1108/09649420410555051

Potter, J. (1996). Representing reality: Discourse, rhetoric and social construction. London: Sage Publications Inc.

Prime, N. (1999). Cross cultural management in South Africa. Pretoria: Van Schaik Publishers.

Rentilla, C. (2006). Me, myself and I. Entrepreneur, 34(12), 102-103.

Rigdon, S., \& Hymowitz, Y. (1992). Race in the workplace: For Black men success resolves a few problems. The Wall Street Journal, 234-245.

Rousseau, D.M. (2004). Assessing organisational culture: The case for multiple methods. In B. Schneider (Eds.), Organisational climate and culture (pp. 153192). San Francisco: Jossey-Bass.

Schriescheim, C., \& Tsui, A.N. (1980). Development and Validation of a Short Satisfaction Instrument for Use in Survey Feedback Interventions. Paper represented at the Western Academy of Management Meeting.

Simpson, R. (2000). Gender Mix and Organisational Fit - How Gender Imbalance at Different Levels of the Organisation Impacts on Women Managers. Women in Management Review, 5(1), 5-19. http://dx.doi.org/10.1108/09649420010310173

Steyn, A.G.W., Smit, C.F., Du Toit, S.C.H., \& Strasheim, C. (2000). Modern statistics in practice. Pretoria: Van Schaik Publishers.

Sutherland, M. (2003). Retention of knowledge workers. Unpublished doctoral thesis, University of Johannesburg, Johannesburg, South Africa.

Terre Blanche, M., Durrheim, K., \& Painter, D. (2007). Research in practise. (4th edn.). Cape Town: University of Cape Town Press.

Thomas, D.A., \& Ely, R.J. (1996). Making differences matter: a new paradigm for managing diversity. Harvard Business Review, September-October, 79-90

Thomas, P., \& Bendixen, S. (2000). Labour relations in the new South Africa. Johannesburg: MacMillan.

Trevor, C.O. (2001). Interactions among actual ease-of-movement determinants and job satisfaction in the prediction of voluntary turnover. Academy of Management Journal, 44(4), 621-638. http://dx.doi.org/10.2307/3069407

Van As, D.S. (2001). Executive mobility in a manufacturing environment. Unpublished MBA project report, University of the Witwatersrand, Johannesburg, South Africa.

Woolnough, H.M., \& Davidson, M.J. (2007). Mentoring as a career development tool: Gender, race and ethnicity implications. In D. Bilimoria \& S.K. Piderit (Eds.), Handbook on Women in Business and Management. Cheltenham: Edward Elgar Publishing Ltd.

Yukondi, V., \& Benson, J. (2005). Women in Asian Management: Cracking the Glass Ceiling? Asia Pacific Business Review, 11(2), 39-148. 